https://doi.org/10.18778/7525-598-0.18

Jan Muś

\title{
Implikacje rozpadu Bośni i Hercegowiny dla Serbii i Chorwacji ${ }^{1}$
}

Proces związany $\mathrm{z}$ tworzeniem się nowych państw, jednostek quasi-państwowych oraz terytorialnych i nieterytorialnych podmiotów autonomicznych trwa na obszarze Bałkanów Zachodnich nieprzerwanie od końca lat 80. ubiegłego wieku. Etniczna mapa regionu, a przede wszystkim polityczne aspiracje przywódców poszczególnych grup narodowych ${ }^{2}$ nie pozwalają na definitywne zakończenie tego procesu. Co więcej, pojawianie się kolejnych ognisk zapalnych jest powiązane ze sobą w całym regionie, co było wyraźnie zauważalne np. w kwestii Kosowa, które ogłosiło niepodległość w lutym 2008 r., prowokując tym samym reakcje o charakterze secesjonistycznym w Bośni i Hercegowinie (BiH).

Scenariusz rozpadu Bośni, a dokładnie rzecz ujmując secesja Republiki Serbskiej (RS), wydaje się determinować życie polityczne tego kraju od początku lat 90. ubiegłego wieku. Trwający od tego momentu kryzys polityczny dotyczacy istnienia oraz ustroju wewnętrznego Bośni i Hercegowiny, opiera się przede wszystkim na konflikcie elit politycznych reprezentujących bośniackich Serbów i Boszniaków (bośniackich Muzułmanów). Sytuację komplikuje fakt istnienia także trzeciej frakcji etno-politycznej - bośniackich Chorwatów.

Politycy reprezentujący bośniackich Serbów dążą do zachowania możliwie szerokiej autonomii w ramach Republiki Serbskiej, tj. utrzymania status quo lub wystapienia RS z Bośni i Hercegowiny. W wystapieniu prasowym w marcu $2010 \mathrm{r}$. przywódca bośniackich Serbów Milorad Dodik jednoznacznie zasugerował podział BiH: „Istnieje wiele przykładów wskazujących na fakt, że Bośnia i Hercegowina nie jest państwem, które może egzystować [...]. Bośnia i Hercegowina potrzebuje przede wszystkim pokoju i stabilizacji, i w związku z tym powinniśmy rozważać także opcję pokojowego podziału tego kraju”. Dodik dodał także, że zarówno on, jak i władze RS szanują Porozumienie Pokojowe z Dayton ${ }^{4}$, lecz sa gotowi na

${ }^{1}$ Niektóre elementy tego artykułu ukazały się wcześniej na łamach „EUobserver”: http://euobserver.com/9/27143.

2 Autor używa wyrażeń grupy narodowe, narodowościowe i etniczne przemiennie.

${ }^{3}$ Cyt. za: Dodik says time has come to talk about dissolution of Bosnia and Herzegovina, 23 III 2010, http://daily.tportal.hr/60615/Dodik-says-time-has-come-to-talk-aboutdissolution-of-Bosnia-Herzegovina.html.

${ }^{4} \mathrm{Na}$ mocy tego porozumienia Bośnia i Hercegowina uzyskała obecny kształt konstytucyjny. 
rozmowy dotyczące wszystkich możliwych rozwiązań: „Negocjując zestaw poprawek do konstytucji, który jest nie do zaakceptowania, wierzymy jednocześnie, że nadszedł czas, aby porozmawiać na temat, jak BiH może zostać podzielona w pokojowy sposób" ${ }^{2}$.

Doskonałym przykładem logiki serbskich przywódców w BiH w kwestii przyszłości tego kraju jest jeden z najważniejszych przedwyborczych sloganów partii M. Dodika - Związku Niezależnych Socjaldemokratów (SNSD) - z 2010 r.: „Republika Serbska na zawsze, a Bośnia i Hercegowina dopóki trzeba”. Jego wymowa jest jasna: Serbowie pozostaną w ramach państwa bośniackiego tylko tak długo, jak będzie to konieczne. To RS stanowi wyraz politycznej woli narodu serbskiego w $\mathrm{BiH}^{6}$.

Stanowisko boszniackich przywódców do niedawna stanowiło przeciwieństwo serbskich postulatów. Najlepszym przykładem jest Partia dla Bośni i Hercegowiny (SBiH) Harisa Silajdžicia. Polityk ten domagał się scentralizowania aparatu państwowego oraz likwidacji entitetów. Podkreślał on wielokrotnie, że podział na dwa entitety jest następstwem ludobójstwa, przestępstw wojennych i zbrodni przeciw ludzkości. Równie często krytykowany przez Silajdžicia był tzw. entitetski tryb podejmowania decyzji, który pozwalał przedstawicielom RS lub Federacji BiH blokować podjęcie decyzji na poziomie władz centralnych ${ }^{7}$. Strona serbska uważa weto entitetskie za podstawowe narzędzie obrony interesu narodu serbskiego w BiH oraz samej RS i dlatego stanowczo sprzeciwia się jego likwidacji. Takie stanowisko H. Silajdžicia i jego zwolenników wzmagało tylko nastroje autonomiczne czy separatystyczne wśród bośniackich Serbów.

W czasie październikowych wyborów w $2010 \mathrm{r}$. boszniacki elektorat udzielił poparcia Partii Akcji Demokratycznej (SDA) Bakira Izetbegovicia. Polityk ten, obecnie członek Prezydencji BiH, reprezentuje zdecydowanie bardziej umiarkowane stanowisko, choć nie ukrywa swojej niechęci wobec $\mathrm{RS}^{8}$. W przedwyborczym wywiadzie dla serbskiego dziennika „Nezavisne Novine” z Banja Luki B. Izetbegović zdecydowanie opowiedział się za wzmocnieniem Prezydencji $\mathrm{BiH}$, ale $\mathrm{w}$ ramach istniejących rozwiązań konstytucjonalnych, tj. poprzez głębsze zaangażowanie w nałożone na tę instytucję obowiązki ${ }^{9}$.

Stanowisko bośniackich Chorwatów zawarte zostało w Deklaracji Kreszewskiej przyjętej przez sześć najważniejszych partii reprezentujaccych ten naród, tj.: Chorwacką Wspólnotę Demokratyczną (HDZ), HDZ 1990, Chorwacką Partię

5 Tamże.

${ }_{6}^{6}$ Zob. np. przemówienie M. Dodika z okazji Dnia Republiki Serbskiej: $R S$ sa svakim rođendanom sue jača, „Nezavisne Novine”, 9 I 2011.

7 Więcej na ten temat w kolejnej cześci artykułu.

8 Zob. np.: Izetbegović razočaran ponašanjem Hrvata, „Nezavisne Novine”, 24 VIII 2010 .

${ }^{9}$ Izetbegović: Neslogu zamijeniti kompromisom, „Nezavisne Novine”, 12 IX 2010. 
Prawa (HSP), Chorwacką Partię Chłopską (HSS), Chorwacką Katolicką Unię Demokratyczną (HKDU) oraz Partię Ludową Praca dla Dobrobytu (NSRZB). Przywódcy tych partii jednoznacznie określili cele narodu chorwackiego zamieszkującego Bośnię i Hercegowinę - likwidacja istniejącego dwuentitetskiego systemu i zastapienie go nowym, w którym obok serbskiej i boszniackiej istniałaby także chorwacka jednostka federalna; zagwarantowanie chorwackim przedstawicielom odpowiedniej liczby miejsc w państwowych organach władzy wykonawczej, ustawodawczej i sądowniczej; utrzymanie zasady konsensusu jako narzędzia ochrony interesów poszczególnych narodów zamieszkujących $\mathrm{BiH}^{10}$. Poza konfliktem na linii Boszniacy (centralizacja) i Serbowie (decentralizacja lub podział kraju), istnieje więc także trzecia grupa, bośniackich Chorwatów, którzy dają wyraz niezadowoleniu z istniejącego stanu rzeczy.

Kwestia systemu konstytucyjnego pozostaje nierozwiązana od 1991 r., kiedy rozpoczęła się poważna debata $\mathrm{w} \mathrm{BiH}$ na ten temat, a obecnie funkcjonujący system nie został praktycznie zmieniony od momentu jego przyjęcia w Dayton i w Paryżu w 1995 r. w ramach rozmów pokojowych prowadzonych pomiędzy walczącymi Boszniakami, Chorwatami i Serbami.

Wielu komentatorów i analityków ostrzega i wskazuje na możliwość podziału Bośni i Hercegowiny jako alternatywny model wyjścia z utrzymującej się od wielu lat sytuacji. Scenariusz rozpadu mobilizuje więc zarówno elektorat boszniacki (jako zagrożenie), jak i serbski i chorwacki (jako cel, szansa).

Były Wysoki Przedstawiciel wspólnoty międzynarodowej Paddy Ashdown zwracał uwagę w 2008 r. na zagrożenie rozpadem BiH. „W Bośni ma miejsce straszna ironia. Radovan Karadžić jest w końcu w drodze do Hagi. Ale podział Bośni, który był jego snem, jest teraz bardziej prawdopodobny niż kiedykolwiek od momentu, w którym stał się zbiegiem” - pisał z Sarajewa w 2008 r. na łamach „The Observer”11. Ashdown zauważył również, że „Republika Serbska, twór Radovana Karadžicia, napotkała próżnię w miejscu, które powinna wypełniać polityczna wola i działanie. Premier Republiki Serbskiej, Milorad Dodik, agresywnie niweczy dekadę reform. Utworzył równoległe instytucje i wysłał delegacje do Czarnogóry, aby dowiedzieć się, jak oni [Czarnogórcy - przyp. J.M.] oderwali się od Serbii. Skorzystał z autonomii uzyskanej na podstawie Porozumienia Pokojowego z Dayton, aby podkopać kształt Bośni tym porozumieniem nakreślony. Nie musimy spekulować na temat jego intencji - Dodik sam je wypowiedział. Nie uważa on, że Bośnia i Hercegowina może przetrwać, ani tego nie chce. Nie postrzega Republiki Serbskiej za część państwa, ale za państwo samo w sobie. [...] jego celem jest na pewno pełna autonomia, a prawdopodobnie

${ }^{10}$ Deklaracja Kreszewska dostępna m.in. na stronie Chorwackiej Rady Kultury: http:/hakave.org/index.php?option=com_content\&id=1401. 2008.

${ }_{11}$ Europe needs a wake-up call. Bosnia is on the edge again, „The Observer”, 27 VII 
secesja, uzależniona od wycofania się wspólnoty międzynarodowej lub utraty przez nia zainteresowania"12.

Do podziału Bośni i Hercegowiny namawia wręcz Łukasz Reszczyński, ekspert Zespołu Analiz Fundacji „Amicus Europae” oraz Europejskiego Centrum Analiz Geopolitycznych (ECAG): „Nie ulega watpliwości, że obecny stan Bośni i Hercegowiny nie rokuje dobrze na przyszłość. Siłowe utrzymywanie trzech niechętnych sobie grup narodowościowych w ramach jednej Federacji nie służy nikomu. Stanu takiego nie potrafiły zmienić ani stacjonujące w Bośni siły międzynarodowe, ani potężny strumień gotówki z Brukseli, który wciąż stanowi podstawę budżetu Federacji. Sytuacja jest patowa, gdyż obecny układ wewnętrzny Bośni i Hercegowiny, który z założenia ma uniemożliwiać zdominowanie organów państwowych przez jeden naród, jest nieefektywny. Jego najmniejsza zmiana grozi z kolei tym, przed czym ma on chronić. To jeden $\mathrm{z}$ podstawowych argumentów świadczących o bezsensowności dalszego podtrzymywania bośniackiego tworu, który nie spełnia żadnych przesłanek nowoczesnego państwa"13.

Wspólnota międzynarodowa, a w szczególności Unia Europejska, sprzeciwia się podziałowi Bośni i Hercegowiny. „Unia Europejska nie zaakceptuje ani działań zmierzających przeciw suwerenności i terytorialnej integralności Bośni i Hercegowiny, ani niwelowania przeprowadzonych reform przyblizajacych ten kraj do Unii Europejskiej" - napisali w prasie lokalnej ${ }^{14}$ Catherine Ashton (Wysoki Przedstawiciel ds. wspólnej polityki zagranicznej i bezpieczeństwa UE) i Stefan Fuele (Komisarz ds. Rozszerzenia).

W poniższym tekście chciałbym pokazać, jakie następstwa będzie niósł ze sobą ewentualny rozpad Bośni i Hercegowiny dla Chorwacji i Serbii, a więc dla tych państw sąsiedzkich, które z racji położenia geograficznego, a przede wszystkim swojej struktury etnicznej są żywotnie zainteresowane i stosunkowo głęboko zaangażowane w sytuację wewnętrzną BiH. W drugiej części opracowania odniosę się także do interesu elit politycznych reprezentujących bośniackich Serbów i Chorwatów.

Dla potrzeb tej analizy przyjałem dwa założenia:

Po pierwsze, secesja Republiki Serbskiej doprowadziłaby także do podobnego zachowania bośniackich Chorwatów, którzy zażądaliby połączenia z Chorwacja. Scenariusz taki wydaje się być szczególnie prawdopodobny na obszarze zachodniej Hercegowiny na południu oraz regionu Posawiny na północy kraju.

12 Tamże; P. Ashdown, R. Holbrooke, A Bosnian powder keg, ,The Guardian”, 22 X 2008, http://www.guardian.co.uk/commentisfree/2008/oct/22/ashdown-holbrooke-bosnia-balkandayton.

${ }^{13}$ Ł. Reszczyński, Federacja Bośni i Hercegowiny - co dalej?, „Biuletyn OPINIE” 2010, nr 37, Fundacja „Amicis Europae”, http://fae.pl/publikacje/opinie?gi=2\&page=4.

14 „Dnevni Avaz”, „Nezavisne Novine” i „Vecernji List”. 
Po drugie, zarówno Zagrzeb, jak i Belgrad zostałyby zmuszone do przychylnej dla secesjonistów reakcji. Niewyobrażalna jest negatywna reakcja władz serbskich czy chorwackich w przypadku takiego scenariusza wydarzeń. Potępienie zachowania rodaków w Bośni i Hercegowinie byłoby bardzo źle przyjęte przez wyborców i zakończyłoby się klęską wyborczą. Obydwa te kraje zmuszone by zostały do akceptacji takiego stanu rzeczy.

Ponadto należy przyjać, że obydwa państwa mają oczywisty, choć nieformalny wpływ na sytuację wewnętrzna w tym kraju. Formalne i nieformalne więzy Belgradu i Zagrzebia ze swoimi rodakami w Bośni i Hercegowinie sa wyraźne. Ku takiemu stanowisku skłania kilka przesłanek. Po pierwsze, Republika Serbska w Bośni i Hercegowinie ma serbski charakter narodowy. Geneza RS oraz jej funkcjonowanie w czasie ostatnich dwóch dziesięcioleci wyraźnie wskazuje na fakt, że entitet ten we wszystkich stadiach swojego istnienia był wyrazem politycznej woli bośniackich Serbów. Podstawowym założeniem istnienia tej terytorialno-politycznej jednostki była ochrona interesów Serbów zamieszkujących Bośnię i Hercegowinę. W tym czasie, tj. pod koniec lat 80. i na początku lat 90. serbski interes narodowy definiowany był jako „niechorwacki” i „nieboszniacki” ${ }^{15}$.

Na przełomie lat 80. i 90. ubiegłego stulecia ta część wyborców i przywódców politycznych, która opowiadała się za ignorowaniem wewnętrznych podziałów o charakterze etno-religijnym czy narodowościowym, nie zdobyła wystarczającego wpływu na politykę w Bośni i Hercegowinie, w Serbii czy w Chorwacji. Proces, który w Europie Środkowej charakteryzował się demokratyzacją na wzór liberalnych demokracji zachodnich, w byłej Jugosławii przybrał formę nacjonalizmu. W przypadku Serbów i Chorwatów zamieszkujących wieloetniczną Bośnię i Hercegowinę oznaczało to, że przedkładano interes danej grupy etnicznej nad interes republiki związkowej ówczesnej Jugosławii - Bośni i Hercegowiny.

$\mathrm{Z}$ punktu widzenia polityki, Serbom bośniackim było więc i w dalszym ciagu jest bliżej do Serbów w Belgradzie, Kosowie czy w Chorwacji, niż do bośniackich Chorwatów czy Boszniaków. Analogiczny model funkcjonuje w odniesieniu do Chorwatów, a także od pewnego czasu do Boszniaków.

Nie bez przyczyny nazwy partii politycznych, jak: HDZ, HSS, HSP, Serbska Partia Demokratyczna (SDS) czy Serbska Partia Radykalna (SRS), są takie same w Chorwacji, Bośni i Hercegowinie oraz w Serbii. Poniższa tabela pokazuje etniczna jednolitość większości partii politycznych BiH.

${ }_{15}$ Analogicznie określano oczywiście także interes narodowy boszniacki i chorwacki. Bośniaccy Chorwaci utworzyli wówczas Chorwacką Republike Herceg-Bośni, która nie doczekała się uznania, jakim cieszy się do dnia dzisiejszego RS. Interes boszniacki zakładał zachowanie wspólnego dla trzech narodów państwa, w którym, prawem większości, władzę sprawowaliby Boszniacy. 
Tabela 1. Skład etniczny najważniejszych ugrupowań politycznych Bośni i Hercegowiny

\begin{tabular}{|c|c|c|c|c|}
\hline $\begin{array}{c}\text { Partia } \\
\text { polityczna }\end{array}$ & $\begin{array}{l}\text { Liczba } \\
\text { członków } \\
\text { w sumie }\end{array}$ & $\begin{array}{c}\text { Członkowie } \\
\text { pochodzacy } \\
\text { z Federacji BiH }\end{array}$ & $\begin{array}{c}\text { Członkowie } \\
\text { pochodzący } \\
\text { z RS }\end{array}$ & $\begin{array}{l}\text { Etniczna } \\
\text { przynależność } \\
\text { członków }\end{array}$ \\
\hline 1 & 2 & 3 & 4 & 5 \\
\hline $\begin{array}{l}\text { Chorwacka } \\
\text { Wspólnota } \\
\text { Demokratyczna } \\
\text { (HDZ) }\end{array}$ & 66352 & $79 \%$ & $21 \%$ & $\begin{array}{l}92 \% \text { Chorwatów } \\
4 \% \text { Boszniaków } \\
2 \% \text { Serbów } \\
2 \% \text { pozostali }\end{array}$ \\
\hline $\begin{array}{l}\text { Nowa } \\
\text { Chorwacka } \\
\text { Inicjatywa } \\
\text { (NHI) }\end{array}$ & 3500 & ok. $70 \%$ & ok. $30 \%$ & $\begin{array}{l}\text { Chorwaci najlicz- } \\
\text { niejsi, choć na ob- } \\
\text { szarach miejskich } \\
\text { (Sarajewo, Tuzla, } \\
\text { Travnik, Zenica) } \\
\text { członkami są także } \\
\text { Boszniacy, Ser- } \\
\text { bowie, Żydzi, itd. }\end{array}$ \\
\hline $\begin{array}{l}\text { Partia } \\
\text { Emerytów BiH } \\
\text { (SPU BiH) }\end{array}$ & ok. 60000 & - & - & $\begin{array}{l}\text { Większość człon- } \\
\text { ków to Boszniacy, } \\
\text { ale we władzach } \\
\text { partii zachowany } \\
\text { został parytet od- } \\
\text { powiadający po- } \\
\text { działowi etnicz- } \\
\text { nemu Federacji } \\
\text { BiH }\end{array}$ \\
\hline $\begin{array}{l}\text { Socjaldemokra- } \\
\text { tyczna Partia } \\
\text { BiH (SDP BiH) }\end{array}$ & 47336 & $84,62 \%$ & $15,38 \%$ & - \\
\hline $\begin{array}{l}\text { Ludowa Partia } \\
\text { - Praca ku } \\
\text { Lepszemu (NS } \\
\text { Radom za } \\
\text { Baljitak) }\end{array}$ & 22300 & $60 \%$ & $40 \%$ & $\begin{array}{l}42 \% \text { Boszniacy } \\
35 \% \text { Serbowie } \\
20 \% \text { Chorwaci } \\
3 \% \text { inni }\end{array}$ \\
\hline $\begin{array}{l}\text { Serbska } \\
\text { Radykalna } \\
\text { Partia (SRS) }\end{array}$ & 14000 & & $100 \%$ & $100 \%$ Serbowie \\
\hline $\begin{array}{l}\text { Chorwacka } \\
\text { Partia Prawa } \\
\text { (HSP) BiH }\end{array}$ & 12000 & - & - & $\begin{array}{l}78 \% \text { Chorwaci } \\
20 \% \text { Boszniacy } \\
2 \% \text { Serbowie }\end{array}$ \\
\hline
\end{tabular}


Tabela 1 (cd.)

\begin{tabular}{|c|c|c|c|c|}
\hline 1 & 2 & 3 & 4 & 5 \\
\hline \begin{tabular}{|l|} 
Liberalno- \\
-Demokratyczna \\
Partia BiH \\
(LDS BiH)
\end{tabular} & 2160 & $92 \%$ & $8 \%$ & $\begin{array}{l}85 \% \text { Boszniacy } \\
7 \% \text { Bośniacy (nie } \\
\text { uznajacy obecnie } \\
\text { dominujących po- } \\
\text { działów etnicznych) } \\
5 \% \text { Serbowie } \\
2 \% \text { Chorwaci } \\
1 \% \text { pozostali }\end{array}$ \\
\hline $\begin{array}{l}\text { Obywatelska } \\
\text { Partia } \\
\text { Demokratyczna } \\
\text { (GDS) }\end{array}$ & $\begin{array}{c}\text { ok. } \\
1600\end{array}$ & - & - & $\begin{array}{l}60 \% \text { Boszniacy } \\
15 \% \text { Chorwaci } \\
15 \% \text { Serbowie } \\
10 \% \text { pozostali } \\
\end{array}$ \\
\hline \begin{tabular}{|l|} 
Chorwacka \\
Unia \\
Demokratyczna \\
(HDU) \\
\end{tabular} & 1768 & $100 \%$ & & $100 \%$ Chorwaci \\
\hline $\begin{array}{l}\text { Chorwacka } \\
\text { Chrześcijańska } \\
\text { Unia Demokra- } \\
\text { tyczna (HKDU) } \\
\text { BiH }\end{array}$ & 2000 & $100 \%$ & & 99\% Chorwaci \\
\hline $\begin{array}{l}\text { Socjalistyczna } \\
\text { Partia Republiki } \\
\text { Serbskiej } \\
\text { (SP RS) }\end{array}$ & $\begin{array}{c}\text { ok. } \\
15000\end{array}$ & $5 \%$ & $95 \%$ & $\begin{array}{l}80 \% \text { Serbowie } \\
10 \% \text { Boszniacy } \\
10 \% \text { Chorwaci }\end{array}$ \\
\hline \begin{tabular}{|l|} 
Partia \\
Emerytów \\
Republiki \\
Serbskiej \\
(PS RS)
\end{tabular} & $\begin{array}{c}\text { ok. } \\
11300\end{array}$ & - & - & $\begin{array}{l}\text { Serbowie najlicz- } \\
\text { niejsi. Obecni także } \\
\text { Chorwaci, Bosznia- } \\
\text { cy, Węgrzy, Słowa- } \\
\text { cy, Macedończycy } \\
\text { itp. }\end{array}$ \\
\hline
\end{tabular}

Źródło: Democracy Assessment in Bosnia and Herzegovina, Sarajevo 2006, s. 177-179.

Polityczna wspólnota narodowa, która w przypadku BiH zrzuca na dalszy plan rację stanu w rozumieniu interesu państwa, została wyraźnie podkreślona i ugruntowana na bośniackiej scenie politycznej, praktycznie od początku lat 90. aż do dnia dzisiejszego. Jest ona szczególnie wyraźnie widoczna wśród partii politycznych, reprezentujących poszczególne frakcje etno-polityczne. 
Co więcej, Konstytucja Bośni i Hercegowiny zakłada, że obydwa entitety mają prawo utrzymywania szczególnych stosunków z krajami sąsiedzkimi, biorąc pod uwage jednak obowiązek poszanowania terytorialnej integralności i suwerenności Bośni i Hercegowiny ${ }^{16}$. Konstytucja wspiera więc takie specjalne relacje!

\section{System konstytucyjny BiH a wpływy państw ościennych}

Dzięki specyficznemu systemowi konstytucyjnemu, przedstawiciele zarówno bośniackich Serbów, jak i bośniackich Chorwatów maja olbrzymi wpływ na funkcjonowanie całego państwa, tak w kwestiach prawodawczych, jak i związanych z władzą wykonawczą i sądownicza.

Przedstawiciele poszczególnych grup etnicznych maja zagwarantowane miejsca w obydwu izbach parlamentu państwowego. Pięciu Serbów z Republiki Serbskiej oraz pięciu Boszniaków i pięciu Chorwatów z Federacji Bośni i Hercegowiny zasiada w Izbie Narodów ${ }^{17}$. Niższa izba parlamentu (Izba Przedstawicieli) obsadzona jest w 2/3 przez posłów wybranych z Federacji Bośni i Hercegowiny, pozostała część deputowanych reprezentuje Republikę Serbską ${ }^{18}$. Biorac pod uwagę dominację Chorwatów i Boszniaków w Federacji oraz Serbów w RS, Izba Przedstawicieli jest więc także podzielona według klucza etnicznego. W czasie ostatnich wyborów, które odbyły się jesienią 2010 r., wszyscy posłowie pochodzacy z RS byli Serbami, natomiast wśród deputowanych z Federacji Saša Magazinović, reprezentujący Socjaldemokratyczną Partię BiH (SDP), nie jest ani Chorwatem, ani Boszniakiem. Tak więc poszczególne „narody konstytutywne” Boszniacy, Serbowie i Chorwaci - sa reprezentowane w obydwu izbach Zgromadzenia Parlamentarnego BiH.

Władza wykonawcza także podzielona jest według klucza narodowościowego. Prezydencja Bośni i Hercegowiny składa się z jednego Serba (wybranego z terytorium RS) oraz jednego Chorwata i jednego Boszniaka (wybranych z Federacji BiH) ${ }^{19}$. W 2010 r. wybrani zostali B. Izetbegović (reprezentujacy Boszniaków), Chorwat Željko Komšić oraz Serb Nebojša Radmanović.

Rada Ministrów Bośni i Hercegowiny składa się w 2/3 z ministrów reprezentujących Federację, pozostali jej członkowie reprezentują $\mathrm{RS}^{20}$. Rząd, który funkcjonował w poprzedniej kadencji ${ }^{21}$, składał się z następujacych osób:

\footnotetext{
${ }^{16}$ Art. III 2b Konstytucji BiH.

${ }_{17}$ Art. IV 1 Konstytucji BiH.

${ }^{18}$ Art. IV 2 Konstytucji BiH.

19 Art. V Konstytucji BiH.

${ }^{20}$ Art. V 4b Konstytucji BiH.

${ }^{21} \mathrm{~W}$ czasie przygotowywania tego artykułu nie doszło jeszcze do utworzenia koalicji w nowo wybranym parlamencie.
} 
- Premier - Nikola Špirić (Serb),

- Minister Spraw Zagranicznych - Sven Alkalaj (Żyd), Wiceminister - Ana Trišić-Babić (Serbka), Dyrektor Generalny - Adnan Hadžikapetanović (Boszniak),

- Minister Bezpieczeństwa - Tarik Sadović (Boszniak), Wiceminister Mijo Krešić (Chorwat), Dyrektor Generalny - Bakir Dautbašić (Boszniak),

- Minister Obrony - Selmo Cikotić (Boszniak), Wiceminister - Igor Crnadak (Serb), Wiceminister (struktura Ministerstwa Obrony przewiduje dwóch wiceministrów) - Marina Pendeš (Chorwatka),

- Minister Skarbu Państwa i Finansów - Dragan Vrankić (Chorwat), Wiceminister - Fuad Kasumović (Boszniak), Dyrektor Generalna - Biljana DakićĐurović (Serbka),

- Minister Sprawiedliwości - Bariša Čolak (Chorwat), Wiceminister Srđan Arnaut (Serb), Dyrektor Generalny - Jusuf Halilagić (Boszniak),

- Minister Handlu Międzynarodowego i Międzynarodowych Stosunków Gospodarczych - Mladen Zirojević (Serb), Wiceminister - Vilim Primorac (Chorwat), Dyrektor Generalny - Hamdo Tinjak (Boszniak),

- Minister Komunikacji i Transportu - Božo Ljubić (Chorwat), Wiceminister - Veselin Poljašević (Serb), Dyrektor Generalny - Nikola Šego (Chorwat),

- Minister do spraw Praw Człowieka i Uchodźców - Safet Halilović (Boszniak), Wiceminister - Slavko Marin (Chorwat), Dyrektor Generalny - Dragomir Kovač (Serb).

W tym okresie w Radzie Ministrów zasiadało dwóch Serbów (z czego jeden z nich pełnił stanowisko premiera), trzech Chorwatów, trzech Boszniaków i jeden Żyd. Konstytucja zakłada, że również wiceministrowie powinni reprezentować inny naród niż minister $\mathrm{w}$ danym ministerstwie ${ }^{22}$. Praktyka pokazała, że także stanowiska dyrektora generalnego ministerstwa zostały objęte tym parytetem. W sumie ministerstwami kierowało w tym czasie ośmiu Serbów, ośmiu Chorwatów, ośmiu Boszniaków i jeden Żyd.

Analogiczne rozwiązania przyjęto także na poziomie obydwu entitetów Parlament Federacji BiH jest zreszta identycznie jak parlament państwowy podzielony na Izbę Narodów Federacji BiH oraz Izbę Przedstawicieli Federacji BiH. Parlament RS składa się z Narodowego Zgromadzenia Republiki Serbskiej oraz pełniącej rolę izby wyższej Rady Narodów $\mathrm{RS}^{23}$. Parytet narodowościowy stał się fundamentalną zasadą regulująca obsadzanie stanowisk nie tylko na poziomie centralnym - państwowym, ale także tym niższym, regionalnym i lokalnym. Konstytucja $\mathrm{BiH}$ wprowadziła więc całkowita etnicyzację urzędów publicznych i instytucji politycznych i sądowniczych, gdzie nadrzędną wartością stała się przynależność etniczna.

\footnotetext{
${ }^{22}$ Art. V 4b Konstytucji BiH.

${ }^{23}$ Art. 71 Konstytucji Republiki Serbskiej BiH.
} 
Takie rozwiązanie ma także inne konsekwencje. Wszystkie trzy grupy narodowościowe: Boszniacy, Serbowie i Chorwaci maja swoich reprezentantów w organach państwowych, co rodzi oczywiste konsekwencje odzwierciedlone w kształcie i charakterze prac tych instytucji.

Co więcej, ścieżka legislacyjna zakłada, że każda z tych grup może stosunkowo łatwo zablokować proces decyzyjny tak w parlamencie, jak i w Prezydencji BiH. W Izbie Narodów trzech z pięciu delegatów reprezentujących dany naród może zawetować propozycję legislacyjną ze względu na zagrożenie dla szeroko rozumianego żywotnego interesu danej grupy narodowościowej. Proces decyzyjny w parlamencie może być także skutecznie zablokowany przez $2 / 3$ posłów reprezentujących jeden $\mathrm{z}$ entitetów, tj. w Izbie Narodów siedmiu Boszniaków i Chorwatów, lub czterech Serbów ${ }^{24}$, a w Izbie Przedstawicieli dziesięciu przedstawicieli RS i dziewiętnastu posłów z Federacji $\mathrm{BiH}^{25}$.

W Prezydencji BiH decyzje podejmowane są na zasadzie konsensusu, a każdy z członków prezydencji może, odwołując się do potrzeby ochrony żywotnego interesu jednego $\mathrm{z}$ entitetów, taki konsensus złamać ${ }^{26}$. Poszczególne narody konstytutywne są więc nie tylko reprezentowane na zasadzie dominującego parytetu etnicznego, ale także mają zdecydowany wpływ na procedurę legislacyjną, która zakłada konieczność istnienia konsensusu dotyczącego kierunku rozwoju państwa, społeczeństwa czy gospodarki.

Co to oznacza? Otóż biorąc pod uwagę narodowościowy raczej niż państwowotwórczy charakter poszczególnych frakcji etno-politycznych możemy przyjąć, że Serbowie i Chorwaci, także ci z Zagrzebia czy Belgradu, mają znaczny wpływ na to, co się dzieje w Bośni i Hercegowinie, pozornie suwerennym podmiocie prawa międzynarodowego. Wpływ ten jest na tyle silny, że poszczególne frakcje są w stanie zablokować cały proces decyzyjny na długie miesiące i lata. Doskonałym przykładem jest fakt nieuznania Kosowa przez władze Bośni i Hercegowiny, co zostanie przeanalizowane poniżej w tym artykule.

Sama liczba sesji parlamentarnych, które odbyły się pomiędzy 1996 i 2008 r. świadczy o niewielkiej aktywności tego organu legislacyjnego.

Dla porównania posłowie do Sejmu RP w czasie przedostatniej, V kadencji spotkali się 87 razy na 2-3-dniowych posiedzeniach, w czasie IV kadencji posiedzeń było 109. Jeśli jednak przyjrzymy się liczbie podjętych decyzji dysproporcja będzie olbrzymia. W latach 2001-2005 Sejm przyją prawie 900 ustaw, podczas gdy parlament BiH tylko koło 200.

\footnotetext{
${ }^{24}$ Art. IV 3e, f Konstytucji BiH.

${ }_{25}$ Art. IV 3d Konstytucji BiH.

${ }^{26}$ Art. V 2c, d Konstytucji BiH.
} 
Tabela 2. Sesje Zgromadzenia Parlamentarnego BiH

\begin{tabular}{|c|c|c|c|c|}
\hline \multirow{2}{*}{ Lata } & \multicolumn{2}{|c|}{ Izba Przedstawicieli } & \multicolumn{2}{c|}{ Izba Narodów } \\
\cline { 2 - 5 } & $\begin{array}{c}\text { liczba sesji } \\
\text { parlamentar- } \\
\text { nych }\end{array}$ & $\begin{array}{c}\text { liczba punktów } \\
\text { porządku } \\
\text { dziennego }\end{array}$ & $\begin{array}{c}\text { liczba sesji } \\
\text { parlamentar- } \\
\text { nych }\end{array}$ & $\begin{array}{c}\text { liczba punktów } \\
\text { porządku } \\
\text { dziennego }\end{array}$ \\
\hline $1996-1998$ & 11 & 76 & 12 & 64 \\
\hline $1998-2000$ & 26 & 199 & 24 & 147 \\
\hline $2000-2002$ & 32 & 335 & 24 & 336 \\
\hline $2002-2006$ & 84 & 1329 & 63 & 1904 \\
\hline $2006-2008$ & 25 & 370 & 14 & 297 \\
\hline
\end{tabular}

Źródło: K. Trnka, Evaluacija procesa odlučivanja u Parlamentarnoj Skupštini BiH 1996-2007. godine, [w:] Procesa odlučivanja u Parlamentarnoj Skupštini Bosne i Hercegovine. Stanje - komparativna rješenja - prijedlozi, Sarajevo 2009, s. 76.

Tabela poniżej przedstawia proces legislacyjny z innej perspektywy, wyjaśniając powody odrzucenia propozycji ustawodawczych.

Jeśli więc wziąć pod uwagę proces decyzyjny i reprezentację poszczególnych grup narodowościowych w demokratycznie wybieranych organach władzy, Bośnia i Hercegowina to państwo, gdzie istnieje permanentna potrzeba konsensusu pomiędzy przedstawicielami Serbów, Boszniaków i Chorwatów. Każda z tych grup ma bowiem możliwość zablokowania procesu decyzyjnego.

$\mathrm{W}$ momencie istnienia wspólnego politycznego interesu pomiędzy reprezentantami Chorwatów w Bośni i Hercegowinie oraz w Chorwacji, a także pomiędzy Serbami zamieszkującymi Republikę Serbską BiH oraz Serbię właściwa, możemy przyjąc, że Belgrad i Zagrzeb mają wpływ na wydarzenia w Sarajewie dużo większy niż w przypadku relacji pomiędzy państwami, które łączą dobrosąsiedzkie stosunki. Rozpad $\mathrm{BiH}$ doprowadziłby do oczywistego zniknięcia tych wpływów, przy jednoczesnym pojawieniu się wielu pytań i zagrożeń płynących z ponownego kształtowania się granic państwowych na tym obszarze Europy.

\section{Proces integracji europejskiej i terytorialna integralność Bośni i Hercegowiny}

Chorwacja i Serbia znajdują się dziś na drodze do członkostwa w Unii Europejskiej. Chorwacja weszła w ostatnią fazę procesu akcesyjnego. W momencie przygotowywania tego opracowania dokładna data przystapienia Chorwacji do Unii nie była znana, jednak można stwierdzić, że negocjacje akcesyjne mogą zakończyć 


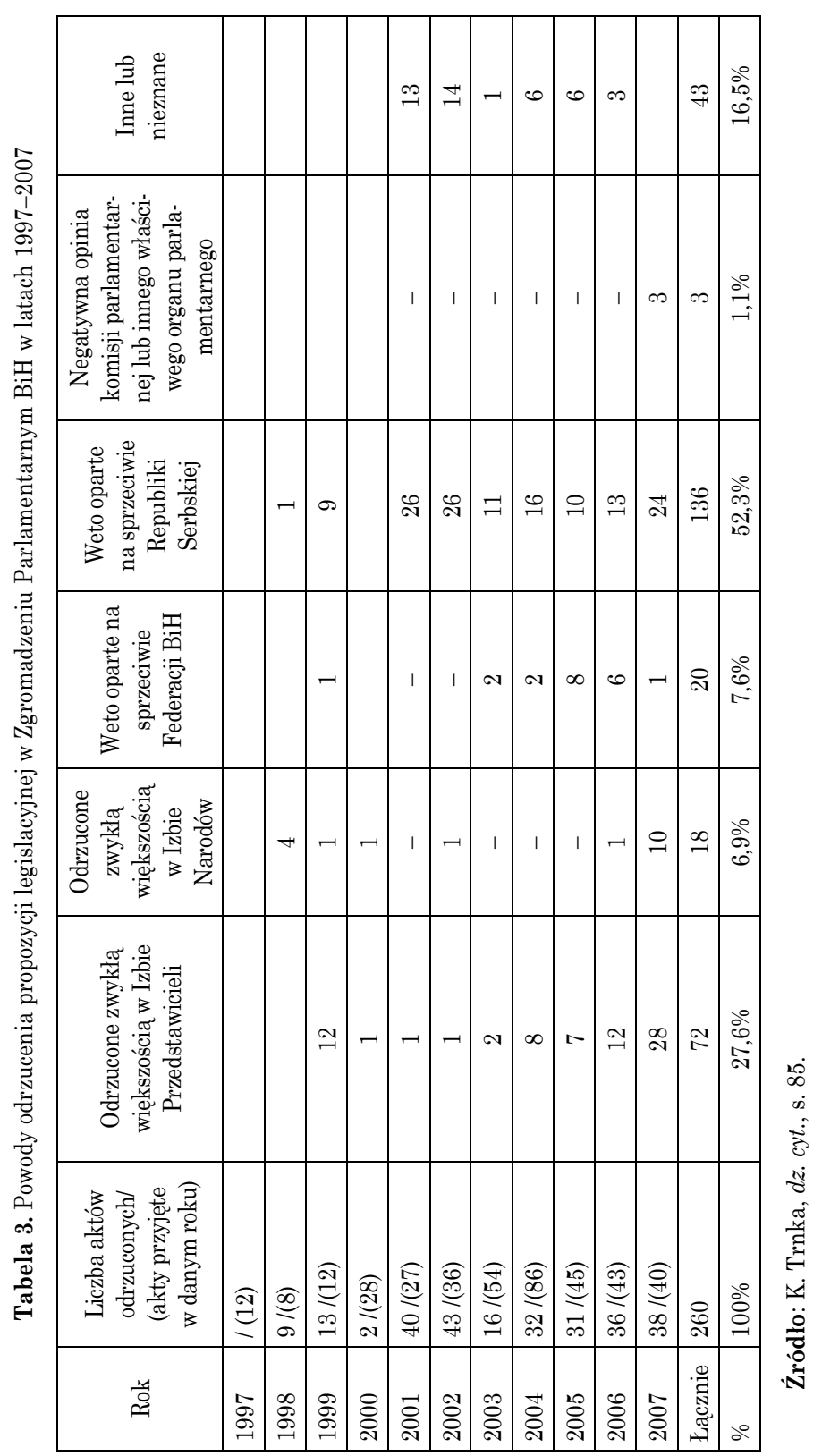


się $\mathrm{w}$ ciagu najbliższych kilku-kilkunastu miesięcy, natomiast sam moment uzyskania członkostwa przypadnie na 2013 lub 2014 r. Choć Chorwacja jest już w przedsionku Unii Europejskiej, to pozostaje jeszcze wiele możliwości skutecznego wydłużenia tego procesu o kolejne miesiące czy lata. Po zakończeniu negocjacji musi bowiem zostać podpisany traktat akcesyjny, który z kolei podlega obowiązkowi ratyfikacji przez wszystkie dwadzieścia siedem państw członkowskich. Innymi słowy, choć cel wydaje się być blisko, to jego osiagnięcie może się znacząco oddalić.

Serbię z kolei czeka jeszcze dłuższa droga do członkostwa. Mianowicie, po niedawnym zwrocie do Komisji Europejskiej kwestionariusza, Serbia stara się o uzyskanie statusu kandydata i wyznaczenie daty rozpoczęcia negocjacji akcesyjnych. Te z kolei trwaja z reguły latami. Najlepszym przykładem jest tutaj Macedonia, która pomimo uzyskania statusu państwa-kandydata w 2005 r. nie rozpoczęła jeszcze negocjacji akcesyjnych. Powodem jest brak zgody niektórych państw członkowskich UE, przede wszystkim Grecji, na przystapienie do rozmów.

Choć moment przystapienia Serbii do Unii jest jeszcze odległy, to faktem pozostaje postępująca integracja zarówno Serbii, jak i Chorwacji ze zjednoczoną Europa ze wszystkimi tego następstwami gospodarczymi, społecznymi, finansowymi i politycznymi. Obecnie Chorwacja otrzymuje około $150 \mathrm{mln}$, a Serbia 190 mln euro rocznie w ramach pomocy przedakcesyjnej ${ }^{27}$. Rozpad $\mathrm{BiH}$, czemu zdecydowanie sprzeciwia się UE, postawiłby obydwa omawiane państwa w ciężkim położeniu. Z jednej strony musiałyby wyjść naprzeciw oczekiwaniom swoich rodaków w Bośni i Hercegowinie oraz istotnej części rodzimego elektoratu. Należy bowiem przyjąć, że nacjonalistycznie nastawiona część społeczeństwa, a w obydwu krajach wynosi ona między $30 \%$ a $50 \%$ wyborców popierających partie o silnym zabarwieniu nacjonalistycznym, domagać się będzie „wyciagnięcia ręki” do rodaków za granicą i połączenia serbskich, względnie chorwackich ziem z macierza. Szczególnie w Serbii tego typu reakcja musiałaby zostać wzięta pod uwagę. Ciężko jest bowiem sobie wyobrazić sytuację, w której obecny rząd traci kontrolę nad Kosowem, a jednocześnie ignoruje polityczne aspiracje rodaków za granicą zmierzające ku połączeniu „serbskich ziem” w jedną całość.

Takie zachowanie wywołałoby ostrą reakcję Unii i zdecydowanie pogorszyłoby relację z kluczowymi państwami europejskimi oraz opóźniło proces integracji europejskiej. Unia Europejska opowiada się za terytorialną integralnością tego państwa. Rozpad Bośni wywołany secesją Serbów i/lub Chorwatów doprowadziłby do utraty prestiżu międzynarodowego UE. Najprawdopodobniej bowiem oznaczałoby to destabilizację regionu, a poprzez to podawałoby w wątpliwość efektywne działanie UE na forum międzynarodowym.

${ }^{27}$ Zob. http://ec.europa.eu/enlargement/how-does-it-work/financial-assistance/index_en.htm. 
Warto także zwrócić uwagę na powody państw członkowskich UE, które nie uznają niepodległości Kosowa. Pomimo przyjacielskich gestów pomiędzy Belgradem a Madrytem, Bratysława, Bukaresztem, Atenami i Nikozją nie należy zapominać, że państwa te sa przeciwne secesji Kosowa z bardzo pragmatycznych powodów, odnoszących się bezpośrednio do sytuacji wewnętrznej tych państw. Jest to szczególnie wyraźne w przypadku Hiszpanii, w której trwa decentralizacja władzy, a takie regiony, jak Kraj Basków czy Katalonia, zyskują coraz więcej poparcia w Andaluzji czy Galicji. Słowacja obawia się wzrostu nastrojów separatystycznych wśród zamieszkujących tam Węgrów. Cypryjscy Grecy chca z kolei zjednoczenia swojej wyspy, a nie utrwalenia jej podziału poprzez przyznanie prawa do secesji innym narodom.

Nie można więc oczekiwać, że państwa popierające serbskie stanowisko w sporze z Kosowem, jak Hiszpania, Słowacja czy Cypr, zmienia zdanie i zaczna popierać ruchy separatystyczne. Rozpad BiH mógłby doprowadzić do nieuznania go przez część państw członkowskich UE, a więc, jak to ma miejsce w przypadku Kosowa, także przez samą Unię. Wątpliwe, aby przywódcy z Zagrzebia i Belgradu chcieli stanąc w sytuacji wyboru pomiędzy odpowiednio zachodnią Hercegowiną i wschodnią Bośnią a członkostwem w UE.

\section{Zjednoczenie jako wyzwanie}

Chorwacja i Serbia, po ewentualnym przyłączeniu poszczególnych ziem Bośni i Hercegowiny, stanęłyby przed nie lada wyzwaniem gospodarczym oraz politycznym. Po pierwsze, integracja gospodarcza tych ziem wymagałaby znacznych nakładów finansowych i administracyjnych, którymi państwa te obecnie nie dysponuja.

Zjednoczenie Niemiec kosztowało w ciagu dwudziestu lat 1,3 bln euro ${ }^{28}$ ! Oczywiście Republika Serbska czy zachodnia Hercegowina to zupełnie inna skala, jednak pewnych kosztów nie dałoby się uniknąć, kosztów, które ponieść musiałyby przecież Serbia i Chorwacja. Przyłączenie poszczególnych części Bośni i Hercegowiny do Serbii i Chorwacji nie wpłynęłoby także pozytywnie na gospodarkę obydwu tych krajów. Niestety, obecne trendy rozwoju społeczno-ekonomicznego pozostawiły $\mathrm{BiH}$ daleko w tyle. Ziemie te wraz z niewystarczajaco rozwinięta infrastruktura, wysokim bezrobociem, zorganizowaną przestępczością czy korupcją stanowiłyby dla Zagrzebia i Belgradu obciążenie przez kolejne dziesięciolecia.

${ }^{28}$ D. Graham, Study shows high cost of German reunification: report, http://www.reuters.com/ article/2009/11/07/us-germany-wall-idUSTRE5A613B200 91107. 
Co więcej, poza kwestiami gospodarczymi należy także wziąć pod uwagę aspekty polityczne. Czy rządzące elity w Serbii są w stanie przewidzieć, w jaki sposób głosować będą nowi obywatele? Choć obecnie nie ma problemu, aby przeprowadzić ankiety i dokonać analizy politycznych sympatii serbskiego elektoratu w BiH, to należy podkreślić, że rozpad Bośni doprowadziłby do poważnego zamętu politycznego, a w krajach, które przechodzą transformację, oznacza to z reguły zmianę rządu. Secesja Republiki Serbskiej i połączenie tych ziem z Serbią byłoby wydarzeniem o nieprzewidywalnych skutkach politycznych.

W przypadku Chorwacji zmiany są bardziej przewidywalne. Większa część elektoratu bośniackich Chorwatów głosuje na HDZ. Oznacza to jednakże, że podczas gdy HDZ pozostawać będzie w opozycji w Saborze, zjednoczenie ziem zamieszkałych przez Chorwatów może napotkać na dodatkowe poważne komplikacje ze strony władz w Zagrzebiu.

Zjednoczenie ziem zamieszkiwanych przez Serbów i Chorwatów w ramach dwóch organizmów państwowych stanowiłoby więc olbrzymi problem finansowy i gospodarczy, a przywódcom tych krajów nie gwarantowałoby sukcesu politycznego wyrażonego w wyborach.

\section{Rozpad Bośni i Hercegowiny a integralność terytorialna Serbii}

Secesja Serbów i Chorwatów mogłaby doprowadzić do wysuwania podobnych żądań przez np. Boszniaków zamieszkujących Sandżak, w południowej Serbii. Zgodnie z cenzusem przeprowadzonym w 2002 i 2003 r. Boszniacy stanowili 45,93\% ludności Sandżaku, podczas gdy Serbowie 36,36\%. Już obecnie widać mobilizację etno-polityczną Boszniaków sandżackich. Szczególnie agresywny ton, choć pomijający kwestię secesji, ma retoryka jednego $\mathrm{z}$ najbardziej wpływowych przywódców w regionie - Muamera Zukorlicia, muftiego Serbskiej Wspólnoty Islamskiej ${ }^{29}$. Choć na chwilę obecną taki scenariusz jest raczej mało realny, to nieroztropne byłoby wykluczenie takiego rozwoju wydarzeń za np. dziesięć lat.

\section{Bośnia a Kosowo}

Kolejnym ważnym argumentem przemawiającym przeciw rozpadowi Bośni i Hercegowiny jest kwestia niepodległości Kosowa. Scenariusz rozpadu BiH oznaczałby utratę jakichkolwiek znaczacych argumentów na rzecz ponownej integracji Kosowa z Serbia. Zasada poszanowania integralności terytorialnej

${ }^{29}$ Wywiad z Cristiną Zuber z Instytutu Politologii Porównawczej na Uniwersytecie w Kolonii przeprowadzony w styczniu $2011 \mathrm{r}$. 
dotyczy wszystkich suwerennych państw. Ograniczając się jednakże do podgrzewania atmosfery wokół secesji bośniackich Serbów, Belgrad może uzyskać kolejne argumenty na swoją korzyść w sporze z Prištiną.

Jako ciekawy przykład można podać wywiad, którego udzielił we wrześniu 2009 r. serbski Minister Spraw Wewnętrznych Ivica Dačić. Ostrzegł on, że Bałkany sa w dalszym ciagu „beczka prochu” i istnieje kilka detonatorów, które moga ją wysadzić. Podkreślił stosowanie podwójnych standardów narzucanych przez wspólnotę międzynarodową w odniesieniu do Kosowa, i do Republiki Serbskiej, której odmawia się niezależności. „Na Bałkanach wiele kwestii pozostaje nierozwiązanych, sa one tylko zamiecione pod dywan" - powiedział I. Dačić wskazując na współzależność kazusu Kosowa i serbskiego entitetu w Bośni i Hercegowinie. Dačić stwierdził także, że Republika Serbska w dalszym ciagu może liczyć na pełne poparcie dla zachowania status quo odnośnie do wewnętrznego podziału Bośni i Hercegowiny, przyjętego porozumieniem z Dayton. $\mathrm{Z}$ drugiej strony M. Dodik wyraźnie dał do zrozumienia, że serbscy przedstawiciele w instytucjach państwowych Bośni i Hercegowiny nigdy nie dopuszcza, aby państwo to uznało niepodległość Kosowa ${ }^{30}$.

Łączenie sprawy Kosowa z rozpatrywaniem kwestii oderwania się Republiki Serbskiej od Bośni i Hercegowiny jest w dwójnasób korzystne dla Belgradu, choć paradoksalnie nie znaczy to wcale, że Belgrad taka secesję będzie wspierał. Po pierwsze, zakładany scenariusz secesji bośniackich Serbów jest ważnym argumentem przeciw wymuszaniu na Serbii uznania niepodległości Kosowa. Po drugie, Bośnia i Hercegowina funkcjonująca w ramach systemu konstytucyjnego przyjętego w Dayton nie uzna niepodległości Kosowa, dopóki sam Belgrad się na to nie zgodzi i w taki sposób staje się nolens volens sojusznikiem Serbii w tej sprawie.

Patrząc z innej perspektywy, obecna sytuacja polityczna w Bośni i Hercegowinie jest korzystna dla Serbii i Chorwacji z co najmniej kilku powodów. Obydwa te państwa mają wyjątkowy wpływ na sytuację wewnętrzna w BiH. Dzieje się tak, jak wykazaliśmy powyżej, ze względu na liczna grupę bośniackich Serbów i Chorwatów zamieszkujących Bośnię oraz na specyficzny system konstytucyjny tego kraju. Niestabilność BiH może łatwo być wykorzystana przez Serbię i Chorwację jako pretekst do podkreślenia swojej „wyjątkowej” roli w regionie, jako państw wpływowych, znaczących. Wizyty prezydentów Borisa Tadicia czy Ivo Jospiovicia w Bośni i Hercegowinie bardzo pozytywnie wpływaja na ich wizerunek na świecie, a szczególnie w Brukseli, Berlinie i Paryżu. Państwa pragną być postrzegane jako odgrywające kluczową rolę w trwałej stabilizacji politycznej nie tylko Bośni i Hercegowiny, ale także całego regionu. Wpływa to

${ }^{30}$ Wywiad dostępny na: http://daily.tportal.hr/84911/Serbian-minister-Balkans-still-apowder-keg.html. 
w oczywisty sposób na pozycję Zagrzebia i Belgradu w stosunkach z Unią Europejska.

Niestabilna i nierozwinięta gospodarczo Bośnia i Hercegowina stanowi rezerwę taniej siły roboczej (przede wszystkim dla Chorwacji) oraz rynek zbytu dla serbskich i chorwackich produktów. Obecnie bilans handlowy BiH z jej sassiadami jest wysoce niekorzystny.

Tabela 4. Bilans handlu zagranicznego Bośni i Hercegowiny (w mln euro) w latach 2008-2010

\begin{tabular}{|l|c|c|c|}
\hline \multicolumn{1}{|c|}{ Państwo } & Import do $\mathrm{BiH}$ & Eksport z BiH & Bilans \\
\hline Chorwacja & 3347,01 & 1587,30 & minus 1759,71 \\
\hline Serbia & 2219,22 & 1289,12 & minus 930,1 \\
\hline
\end{tabular}

Źródło: dane Ministerstwa Handlu Zagranicznego i Międzynarodowych Stosunków Gospodarczych, http://www.mvteo.gov.ba/izvjestaji_publikacije/izvjestaji/ANALIZA\%20.pdf.

W ciagu trzech ostatnich lat bilans handlowy Chorwacji i Serbii w obrotach z Bośnią i Hercegowiną był z wyraźną korzyścią dla obydwu tych krajów. Gospodarcza niewydolność BiH oraz wysokie bezrobocie i przerośnięta administracja sprawiaja, że państwo to nie może konkurować ze swoimi dwoma większymi sąsiadami.

\section{Przywódcy bośniaccy a rozpad kraju}

Wielce wątpliwe jest, aby rozpad Bośni i Hercegowiny był poważnie brany pod uwage także przez przywódców bośniackich Serbów i Chorwatów. Podział kompetencji $\mathrm{BiH}$ oznacza, że prawie wszystkie kwestie dotyczące finansów, gospodarki, polityki socjalnej, spraw wewnętrznych, sądownictwa, rolnictwa, energetyki, infrastruktury, podatków itp. należą do entitetów bądź kantonów. Spowodowało to wzrost liczby pozycji ministerialnych do ponad 200. Istnieja przecież rządy poszczególnych kantonów, których jest 10, rządy dwóch entitetów oraz rzą centralny, istnieje także osobna administracja w Dystrykcie Brčko. Każdy z tych rządów ma premiera i poszczególnych członków wraz z wiceministrami, asystentami, kierowcami, sekretarkami itp. Oznacza to, że istniejacy porządek konstytucyjny wyraźnie opłaca się nepotycznym elitom politycznym.

Inny argument dotyczy także podziału kompetencji oraz sporu politycznego, jaki ma miejsce w BiH od uzyskania w 1992 r. niepodległości. Spór ten bowiem kieruje uwagę opinii publicznej na poziom centralny - państwowy, gdzie w najbardziej widoczny sposób ścierają się różne idee rozwiązania problemu bośniac- 
kiego. Podział kompetencji z kolei pozwala na decydowanie o większości aspektów funkcjonowania państwa na poziomie entitetów i/lub kantonów. Innymi słowy, politycy podejmujący decyzję na szczeblu regionalnym przerzucają odpowiedzialność na oponentów na szczeblu centralnym. Powszechnie znanym faktem jest obarczanie winą za kwestie gospodarcze polityków wywodzących się z innego entitetu, podczas gdy bezsprzecznie najwięcej kompetencji w tej dziedzinie pozostaje na szczeblu regionalnym.

Warto zadać sobie pytanie, co się stanie z przywódcami Republiki Serbskiej i bośniackich Chorwatów po przyłączeniu do Serbii i do Chorwacji. Z pozycji głównych rozgrywających $\mathrm{w}$ państwie zostaliby zdegradowani do przywódców regionalnych o znaczeniu podrzędnym. Rozpad Bośni i Hercegowiny oznaczałby przede wszystkim spadek prestiżu i pozycji przywódców bośniackich.

\section{Konkluzje}

To Serbii i Chorwacji oraz bośniackim elitom politycznym powinno zależeć na integralności terytorialnej $\mathrm{BiH}$. Rozpad tego kraju byłby wielce niekorzystny nie z punktu widzenia etyki, moralności, powinności historycznej czy innych, często przytaczanych argumentów, ale przede wszystkim z powodu kosztów, na jakie zostałyby narażone Serbia i Chorwacja oraz utraty korzyści, których beneficjentami są współczesne elity polityczne Bośni i Hercegowiny.

Ciężko jest przewidywać polityczny rozwój sytuacji na Bałkanach, jednak argument rozpadu $\mathrm{BiH}$, podnoszony często w regionie, jest zupełnie bezzasadny. Można wręcz założyć, że jest on używany jako straszak i jednocześnie pusty argument w rozmowach dotyczących przyszłości Bośni i Hercegowiny. Taki scenariusz jest wysoce niepożądany przede wszystkim przez elity serbskie i chorwackie, a więc prawdopodobieństwo jego realizacji także znacząco maleje. 